\title{
ESPOSITO (John L.), éd., The Oxford Encyclopedia of
} the Modem Islamic World

4 vol., New York-Oxford, Oxford University Press, 1995, 466, 476, 475 et 460 p. (index)

\section{Christian Décobert}

\section{CpenEdition}

\section{Journals}

Édition électronique

URL : http://journals.openedition.org/assr/20638

DOI : $10.4000 /$ assr.20638

ISSN : 1777-5825

Éditeur

Éditions de l'EHESS

\section{Édition imprimée}

Date de publication : 1 juillet 2000

Pagination : 115-116

ISBN : 2-222-96691-4

ISSN : 0335-5985

Référence électronique

Christian Décobert, «ESPOSITO (John L.), éd., The Oxford Encyclopedia of the Modem Islamic World», Archives de sciences sociales des religions [En ligne], 110 | avril-juin 2000, document 110-60, mis en ligne le 19 août 2009, consulté le 21 septembre 2020. URL : http://journals.openedition.org/assr/ 20638 ; DOI : https://doi.org/10.4000/assr.20638

Ce document a été généré automatiquement le 21 septembre 2020

(c) Archives de sciences sociales des religions 


\title{
ESPOSITO (John L.), éd., The Oxford Encyclopedia of the Modem Islamic World
}

4 vol., New York-Oxford, Oxford University Press, 1995, 466, 476, 475 et

460 p. (index)

\author{
Christian Décobert
}

\section{RÉFÉRENCE}

ESPOSITO (John L.), éd., The Oxford Encyclopedia of the Modem Islamic World., 4 vol., New York-Oxford, Oxford University Press, 1995, 466, 476, 475 et 460 p. (index)

Cette encyclopédie comble clairement un vide. Alors que la demande d'information sur l'Islam contemporain (avec la majuscule, au sens de monde islamique et non pas seulement de religion) a grandi considérablement depuis une ou deux décennies, il n'y avait pas d'ouvrage de référence d'un maniement immédiat. L'Encyclopédie de l'Islam, dont la deuxième édition progresse très lentement, est peu axée sur le monde moderne ; la Cambridge History of Islam (parue en 1970) est d'un maniement difficile et elle opère une distinction peu convaincante (au moins pour l'âge moderne) entre un « Islam central » et un proliférant « Islam périphérique ». On ne pourra donc que saluer cette parution.

2 Sous la direction de J.L.E. et d'un solide conseil éditorial, quelque 455 contributeurs ont rédigé 750 notices. Tentant d'embrasser tous les aspects possibles de la vie sociale et religieuse de l'Islam moderne, les notices ont été conçues autour de cinq grandes catégories thématiques: "Islamic thought and practice », "Islam and politics », "Muslim communities and societies », "Islam and society " et «Islamic studies ». Certaines des notices, dont les objets sont majeurs dans l'une de ces catégories, sont de véritables essais de synthèse ; d'autres, plus brèves, apportent une information directe, 
précise, avec une bibliographie minimale qui permet d'engager une recherche un peu plus poussée.

3 Bien qu'orientée résolument sur l'Islam moderne, cette encyclopédie ne s'abstient pas d'opérer tous les rappels historiques nécessaires : ainsi sont traités, dans des notices certes courtes mais suffisantes, les dynasties, les souverains anciens, les saints et les lettrés, qui pour les musulmans d'aujourd'hui sont les éléments référentiels d'un capital culturel encore prégnant. 